\title{
SIZING OPTIMIZATION OF PV-BATTERY HYBRID FOR PUBLIC LIGHTING SYSTEM
}

\author{
Miroslav MIKITA, Michal KOLCUN, Martin VOJTEK, Michal ŠPES \\ Department of Electric Power Engineering, Faculty of Electrical Engineering and Informatics, \\ Technical University of Košice, Letná 9, 04200 Košice, Slovak Republic, Tel.: +421 556023560 , \\ E-mail:miroslav.mikita@tuke.sk, michal.kolcun@tuke.sk,martin.vojtek@tuke.sk,michal.spes@tuke.sk
}

\begin{abstract}
This paper deals about sizing of hybrid renewable source application to supply power for public lighting system for entire village without connection to the electrical grid. Such hybrid renewable power systems are suitable in remote area where grid connection is unavailable or connection to grid is expensive. Hybrid system in this paper consists from photovoltaic power plant and large battery bank to storage electricity. Battery bank is supposed to be large because time when electricity is needed is completely different from time when photovoltaic power plant produce power from sun.
\end{abstract}

Keywords: photovoltaic, hybrid system, battery, grid- off

\section{INTRODUCTION}

Integrated Renewable Energy System (IRES) has been proposed by various researchers to electrify remote areas. In IRES, energy demand of a remote area is met by using energy potential of locally available renewable energy sources. In this technology, renewable energy sources like solar, wind, MicroHydro Power (MHP), biomass, biogas etc. can be considered for power generation.

IRES have the potential to aggregate benefits such as energy efficiency and energy conservation, resulting from the combination of renewable energy sources. Integrated use of different renewable energy resources minimizes energy storage requirement, increases reliability of power supply and quality of power. For stand-alone applications, these systems are always incorporated with storage devices in order to manage the stochastic behaviour of renewable energy sources like solar and wind. Control system is the heart of IRES that provides the information and communication among various components of system. Control system regulates the output of renewable energy sources and also, generates the signals for scheduling of storage subsystem and dump load. It protects the storage system from overcharging and it help to operate the storage system in prescribed limit. Whenever surplus energy is available, it is sent to storage subsystem to store the surplus energy and if storage system if fully charged, it is wasted in dump load that can be utilized in cooking, water heating, baking etc. Under condition when demand exceeds generation stored energy is used in order to fulfil deficit load demand [1], [2].

Some remote places have not sufficient availability of renewable energy resources, under such conditions it is required to add some conventional option like diesel/petrol/gasoline based generator, along with renewable energy resources to fulfil load demand. As diesel generator based integrated system pollutes the environment, it is therefore analysis of greenhouse gas emission level must be carried out. This scheme is not appropriate for hilly terrain and remote areas as problems associated with transportation of fuel [3].

\subsection{Advantages and disadvantages of hydropower}

In general, a hybrid energy system could be integrated as Fig. 1 shows. This kind of energy systems are called "hybrid" because they include more than one energy source in order to cover a determined electrical load, commonly an

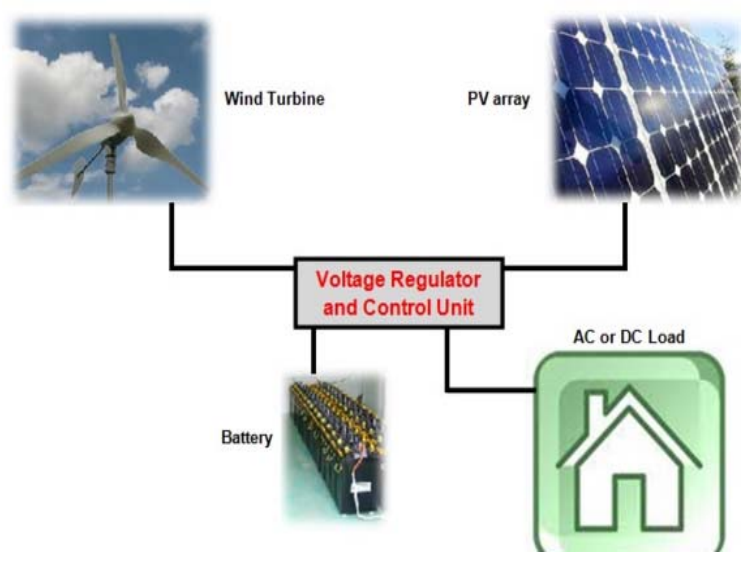

Fig. 1 General hybrid energy system architecture

AC load; however, it may also supply a DC load or both at the same time. Energy sources may be alternative (i.e. renewable) as well as conventional (i.e. electrical grid or diesel generator), or energy storage components (i.e. battery bank or fuel cells); in this way, weakness of some energy sources is complemented by strengths bank or fuel cells); in this way, weakness of some energy sources is complemented by strengths of the other sources in a natural or controlled way. To illustrate that, despite the unpredictable availability of some alternative energy sources (like solar and wind), usually, they present complementary patterns. Hybrid energy systems can operate either in presence of grid (grid-connected) where the main priority of the system is to cater the local energy demand and occasionally to feed the grid with any energy surplus, or as a stand-alone system for producing energy independently of the grid utility in isolated areas. When a hybrid energy system includes solar or wind energy, most 
of times is required an auxiliary source of energy (e.g. coming from battery banks, fuel cells, or utility grid), the aforementioned is in order to overcome the stochastic availability of those energies. Sometimes, depending on the availability of an energy source, it is necessary to find a balance; in other words, a control unit which decides which energy source will supply the electrical load [4], [5].

\section{HOMER}

HOMER is a simulation tool developed by the U.S. National Renewable Energy Laboratory (NREL) to assist in the planning and design of renewable energy based microgrids. The physical behavior of an energy supply system and its lifecycle cost, which is the sum of capital and operating costs over its lifespan, is modelled using HOMER. Options such as distributed generation (DG) units, stand-alone, off-grid and grid-connected supply systems for remote areas, and other design options, can also be evaluated using HOMER. HOMER is designed to overcome the challenges of analysis and design of microgrids, arising from the large number of design options and the uncertainty in key parameters, such as load growth and future fuel prices. Simulation, optimization, and sensitivity analysis are the three principal tasks performed in HOMER [6].

\subsection{Simulation in Homer}

In the area of simulation, HOMER determines technical feasibility and lifecycle costs of a microgrid for each hour of the year. In addition, the microgrid configuration and the operation strategy of the supply components are tested to examine how these components work in a given setting over a period of time. The simulation capability of HOMER is the long-term operation of a microgrid. The optimization and sensitivity analysis of HOMER depends on this simulation capability [7].

\subsection{Sizing optimization in Homer}

In the optimization section, HOMER displays the feasible systems with their configurations under the search space defined by the user, sorted by the minimum cost microgrid depending on the total net present cost. After the simulation finds out the system configuration of a microgrid, the optimization is calculated and displays the optimal microgrid configuration. HOMER defines the optimal microgrid configuration, which is that configuration with the minimum total net present cost and meeting the modeller's constraints [6].

\subsection{Sensitivity analysis}

In this section, the modeller can analyze the effects of parameter variations with time. HOMER finds out the optimal values for the different sizes and quantities of the equipment that is considered in the microgrid and the associated constraints. The sensitivity variables are those variables which have been entered by the user and have different values. The main objective of using the sensitivity analysis in HOMER is that if the user isn't sure which is the best value of a particular variable, then the user will enter different values and the sensitivity analysis will show how the results behave dependent on these values. Many optimizations have to be performed in this section by HOMER, each using different values of input assumptions [8].

\section{MODELLING OF HYBRID SYSTEM}

A hybrid energy grid-off system generally consists of a primary renewable sources as wind and photovoltaic working in parallel with a standby by battery storage units.

Fig. 2 illustrates a small-scale hybrid configuration that will be used as the basis of the case study simulation.

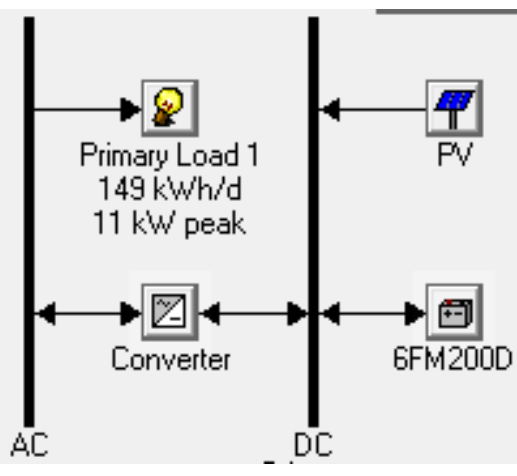

Fig. 2 Implementation of hybrid system

\subsection{Electrical load}

Lighting systems of public lighting comprises a total of 640 pieces of lighting equipment. Power consumption of $18,18 \mathrm{~kW}$ system is ignoring losses. Overall, the lighting major, minor roads and paths used three types of lamps. They are Archilede S power consumption with $36 \mathrm{~W}$, and Archilede E with 27W CARIBONI LEVANTE SMALL 24W. Overview of luminaires and representation can be seen in the the following Table 1 .

Table 1 Types of used lamps

\begin{tabular}{|c|c|c|}
\hline Type of lamp & Input power & Number of pieces \\
\hline Archilede $\mathrm{S}$ & $36 \mathrm{~W}$ & 80 \\
\hline Archilede N & $27 \mathrm{~W}$ & 150 \\
\hline Cariboni & $24 \mathrm{~W}$ & 180 \\
\hline
\end{tabular}

Typical daily energy consumption can be seen on Fig. 3.

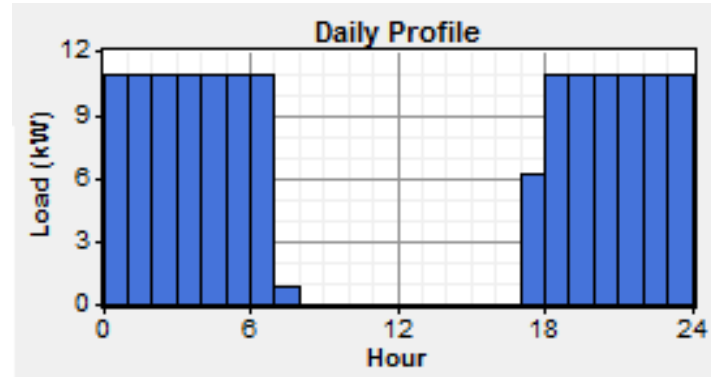

Fig. 3 Daily load profile of simulated public lighting system 


\subsection{Solar irradiance data}

Budimir's monthly solar radiation values are obtained with HOMER from NASA. For coordinates in HOMER, $49^{\circ} 19^{\prime} \mathrm{N}$ latitude and $21^{\circ} 9^{\prime} \mathrm{E}$ longitude are used. This is the coordinates of Centre of Budimir. HOMER syntheses solar radiation values for each $8760 \mathrm{~h}$ of the year by using Graham algorithm. This algorithm produces realistic hourly data, and it is easy to use because it requires only the latitude and the monthly averages. The synthetic data displays realistic day-to-day and hour-to-hour patterns. If one hour is cloudy, there is a relatively high likelihood that the next hour will also be cloudy. Similarly, one cloudy day is likely to be followed by another cloudy day. The synthetic data is created with certain statistical properties that reflect global averages. So data generated for a particular location will not perfectly replicate the characteristics of the real solar resource. But tests show that synthetic solar data produce virtually the same simulation results as real data. Monthly average values of solar data are shown in Fig. 4.



Fig. 4 Solar irradiance profile

\subsection{PV system}

A solar cell is a semiconductor device designed to turn solar irradiance into electricity. If solar cells are connected in series, then the current stays the same and the voltage increases. If solar cells are connected in parallel, the voltage stays the same, but the current increases. Solar cells are combined to form a module to obtain the voltage and current (and therefore the power) desired. A PV array is a group of PV modules put together to generate electricity. A PV array produces DC voltage and current those are used to power the load.

HOMER always deals with the PV array in terms of rated $\mathrm{kW}$, not in $\mathrm{m}^{2}$. So it does not need to know the efficiency. By the way, HOMER assumes that the output of the PV array is linearly proportional to the incident radiation, so if the radiation is $0.75 \mathrm{~kW} / \mathrm{m}^{2}$, the array will produce $75 \%$ of its rated output.

\subsection{Converter}

The inverter and rectifier efficiencies were assumed to be $90 \%$ and $85 \%$ respectively for all sizes considered. HOMER simulated each system with power switched between the inverter and the generator. These devices were not allowed to operate in parallel. In this simple system, power cannot come from both the generator and the batteries at the same time.

Description and value of individual objects in the program is as follows.

\subsection{Batteries}

HOMER uses the Kinetic Battery Model and represents batteries as a "two tank" system. One tank provides immediately available capacity while the second can only be discharged at a limited rate. Vision 6FM200D were chosen because they are a popular and inexpensive option. HOMER considered up to 54 of these batteries. In a real installation a smaller number of larger batteries, such as the Vision 6FM200D, would be preferable. The economic analysis performed by HOMER would not be significantly affected by this distinction. Vision 6FM200D has nominal voltage $12 \mathrm{~V}$ and nominal capacity $200 \mathrm{Ah}$.

\section{SIMULATION RESULTS}

After the system components setting, modelling and simulations of the micro power system is carried out. HOMER, optimization model is used to simulate the system. Large number of options are available for different sizes of the components used, components to be added to the system which make sense, cost functions of components used in the system. HOMER's optimization and sensitivity analysis algorithms evaluated the possibility of system configuration.

Fig. 5 shows optimal sizing of hybrid systems which are based at simulation. This systems can provide full electricity for the model off-grid public ligntning load consumption. This system consist from PV cells field with size $100 \mathrm{~kW}, 180$ batteries Vision 6FM200D and converter with size $12 \mathrm{~kW}$.

\begin{tabular}{|c|c|c|c|c|c|c|c|c|c|}
\hline 甲国 & $\begin{array}{l}\mathrm{PV} \\
(\mathrm{kW})\end{array}$ & 6FM200D & $\begin{array}{l}\text { Conv. } \\
(\mathrm{kW}) \\
\end{array}$ & $\begin{array}{l}\text { Initial } \\
\text { Capital }\end{array}$ & $\begin{array}{l}\text { Operating } \\
\text { Cost }(\$ / y r)\end{array}$ & $\begin{array}{l}\text { Total } \\
\text { NPC }\end{array}$ & \begin{tabular}{|c|}
$\mathrm{COE}$ \\
$(\$ / \mathrm{kWh})$
\end{tabular} & $\begin{array}{l}\text { Ren. } \\
\text { Frac. }\end{array}$ & $\begin{array}{l}\text { Capacity } \\
\text { Shortage }\end{array}$ \\
\hline 甲国图 & 100 & 180 & 12 & $\$ 143,66$ & 2,040 & $\$ 169,746$ & 0.276 & 1.00 & 0.13 \\
\hline
\end{tabular}

Fig. 5 Sizing of calculated hybrid system

Fig. 6 shows daily balance chacteristic. There are showed characteristics of battery state of charge, production from PV field and also load curve.

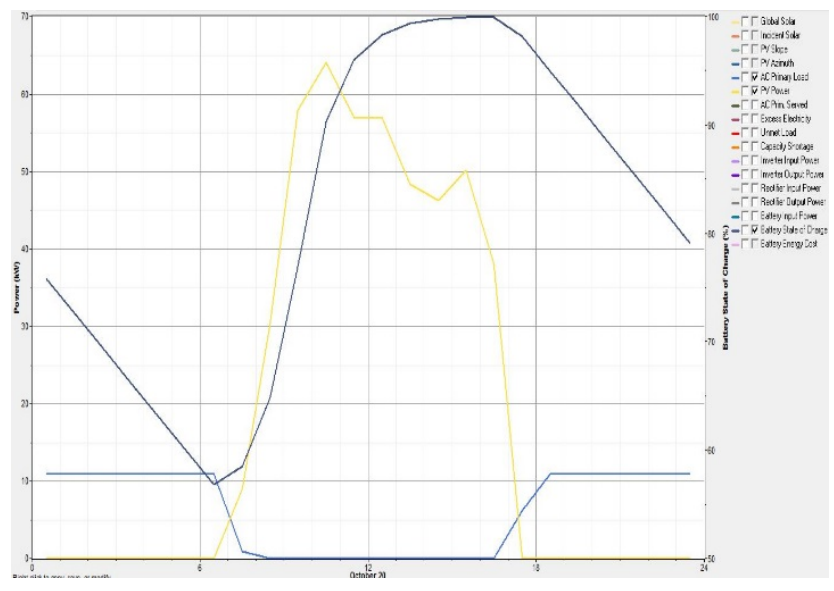

Fig. 6 Sizing of calculated hybrid system 
As it can be seen system cover whole consumption of model house when production is lover than consumption battery bank works as a reserve source of electricity and when production is higher battery bank acumulates surplus of electricity.

\section{CONCLUSION}

The proposed modelled hybrid system fully cover daily consumption of modelled house. System consists from $100 \mathrm{~kW}$ sized PV field, battery bank consists from 180 batteries Vision 6FM200D and converter with size $12 \mathrm{~kW}$. This confirmation caused difference in time of photovoltaic production and time when is public lighting system usually used.

Hybrid systems are suitable way to cover electricity consumption of public lighting systems in areas where good weather conditions are. Choosing optimal sizes of elements of hybrid systems is important from economic view because this systems are expensive and right sizing of elements of hybrid system can reduce amount of money needed for purchase such system. Hybrid systems are solution to bring electricity to remote areas where building grid is expensive or unlikely. In recent days purchasing prices for such systems are getting lower and this systems are becoming available.

\section{REFERENCES}

[1] NEMA, P. - NEMA, R. K. - RANGNEKAR, S.: A current and future state of art development of hybrid energy system using wind and PV-solar: a review Renew Sust Energy Rev, Vol. 13 (8) 2009, pp. 20963103.

[2] BERNAL-AGUSTÍN, J. L. - DUFO-LÓPEZ, R.: Simulation and optimization of stand-alone hybrid renewable energy systems, Renewable and Sustainable Energy Reviews, Vol. 13 (8) 2009, pp. 2111-2118.

[3] ZHOU, W. - LOU, C. - LI, Z. - LU, L. - YANG, H.: Current status of research on optimum sizing of stand-alone hybrid solar-wind power generation systems, in Applied Energy, 87 (2) 2010, pp. 380389.

[4] LUNA-RUBIO, R. - TREJO-PEREA, M. VARGAS-VÁZQUEZ, D. - RÍOS-MORENO, G. J.: Optimal sizing of renewable hybrids energy systems: A review of methodologies, in Solar Energy, Vol. 86 (4) 2012, pp. 1077-1088.

[5] ASHOK, S.: Optimised model for community-based hybrid energy system, in Renewable energy, vol. 32 (7) 2007, pp. 1155-1164.

[6] LAMBERT, T. - GILMAN, P. - LILIENTHAL, P.: Micropower system modelling with HOMER, in Integration of alternative sources of energy, 2006, pp. 379-385.
[7] HAFEZ, O. - BHATTACHARYA, K.: Optimal planning and design of a renewable energy based supply system for microgrids, in Renewable Energy, 2012, Vol. 45, pp. 7-15.

[8] FULZELE, J. B. - DUTT, S.: Optimium planning of hybrid renewable energy system using HOMER, in International Journal of Electrical and Computer Engineering (IJECE), Vol. 2 (1) 2012, pp. 68-74.

Received April 10, 2016, accepted June 2, 2016

\section{BIOGRAPHIES}

Miroslav Mikita is a Ph.D. student in the Department of Electric Power Engineering on the Faculty of Electrical Engineering and Informatics at Technical University of Košice. He received a master degree in electric power engineering on subject designing of pumped hydroelectric power plant. His scientific research is mainly focused on research of renewable sources cooperation.

Michal Kolcun was born in 1954 in Ruska Vol'a nad Popradom, Slovakia. In 1979 he graduated at the Faculty of Electric Power Engineering of the Moscow Power Engineering Institute. In 1989 he defended his $\mathrm{PhD}$ on the same institute in Moscow. In 1993 he habilitated to associated professor at the Department of Electric Power Engineering on the Faculty of Electrical Engineering and Informatics at Technical University of Košice. In 2000 he inaugurate to professor, his thesis title was High-tension electrical power engineering. Since 2006 he is honorary professor at Budapest Polytechnics. Since 1979 he is working with the Department of Electric Power Engineering on the Faculty of Electrical Engineering and Informatics at Technical University of Košice. His scientific research is focusing on a power system control and computer application in electric power engineering. In addition, he also gives lectures in multiple foreign universities in Moscow, Budapest, Riga, Tallinn, Varna, Prague and Ostrava.

Martin Vojtek is a Ph.D. student in the Department of Electric Power Engineering on the Faculty of Electrical Engineering and Informatics at Technical University of Košice. He received a master degree in electric power engineering. His scientific research is mainly focused onnaccumulation of electricity, renewable energy sources and smart grid technologies.

Michal Špes is a Ph.D. student in the Department of Electric Power Engineering on the Faculty of Electrical Engineering and Informatics at Technical University of Košice. He received a master degree in electric power engineering on subject evaluation of generator exciting outage. His scientific research is mainly focused on research of powerline ampacity system. 